\title{
Chromosome Number and Meiotic Behavior of Cultivated Chia, Salvia hispanica (Lamiaceae)
}

\author{
A. Estilai and A. Hashemi \\ Department of Botany and Plant Sciences, University of California, \\ Riverside, CA 92521
}

\section{K. Truman \\ Department of Anthropology, University of California, Riverside, CA 92521}

Additional index words. oilseed crops, new crops, karyotype

\begin{abstract}
Edible chia seeds, purchased from the local markets in Guatemala, Mexico, and southern California, were used for species identification, chromosome counts, karyotype construction, and meiotic analyses. Plants raised from those seeds had ovate leaves, dense racemose inflorescences, pale-blue flowers, and were identified from herbarium specimens as Salvia hispanica $L$. Mitotic analyses of root tips from 50 plants showed $2 n=12$ - the lowest chromosome number in the genus. Chromosomes were small, ranging from 2 to $3.5 \mathrm{pm}$ One pair of chromosomes was metacentric (with the long arm : short arm ratio, $r=1.5)$, four pairs were submetacentric $(r=2.6$ to 3.6$)$, and one pair was telocentric $(r=12)$. Meiosis was regular and six bivalents were observed at metaphase $I$. Ring and rod bivalents averaged $1.53 \pm 1.05$ and $4.47 \pm$ 1.05 , respectively;
\end{abstract}

Chia is the common name for any of several species of Salvia found in Guatemala, Mexico, and the southwestern United States that produce edible oil seeds. Species identified as chia include $S$. hispanica, S. columbariae Benth., S. carduaceae L., S. tiliifolia Vahl., S. polystachya Ort, and $S$. lanceofolia Poir.

Chia was one of the major crops of the Aztec Empire, and in colonial Mexico, it was considered an important oilseed crop (Ortiz de Montellano, 1978; Sanders, 1971).

Received for publication 27 Nov. 1989. Contribution of the College of Natural and Agricultural Sciences, Dept. of Botany and Plant Sciences, UC Riverside. We thank J.G. Waines and P.F. Knowles for reading the manuscript. The cost of publishing this paper was defrayed in part by the payment of page charges. Under postal regulations, this paper therefore must be hereby marked advertisement solely to indicate this fact.
Today, chia oil is used for lacquerware in Mexico. Placed in water, the seed gives off a clear jelly that is mixed with fruit juices to produce pleasant drinks.

Chromosome counts are available for few of the 1000 known Salvia species (Epling, 1938, Epling et al., 1962; Gill, 1971; Haque, 1981; Haque and Ghoshal, 1980; Stewart, 1939; Vij and Kashyap, 1976). Chromosome numbers in the genus Salvia include $2 \mathrm{n}=12,14,16$, $18,20,22,24,26,32,44,54$, and 64. Meiotic studies of chia are nonexistent. Haque and Ghoshal (1980) reported that S. hispanica has very small rod-shaped chromosomes with no clear primary or secondary constrictions in any pair, making it difficult to produce a karyotype for this species.

With interest in development of chia as a source of oil for both dietary and industrial uses in Mexico and the United States, research was undertaken to determine the chromosome number of cultivated chia, de- velop a karyotype, and examine the meiotic behavior.

Chia seed was bought in Guatemala, Mexico, and southern California, the latter being imported from Mexico. For chromosome counts and construction of a karyotype, seeds were germinated in petri dishes at room temperature for $24 \mathrm{~h}$, during which some roots started to emerge. The petri dishes were transferred to a refrigerator and kept at 3 to $4 \mathrm{C}$ for $48 \mathrm{~h}$. They were then placed in the dark at room temperature for $24 \mathrm{~h}$. Root tips were removed and placed in vials containing $2 \mathrm{ml}$ of distilled water. The vials were placed in crushed ice and refrigerated for 22 to 24 h. Root tips were fixed at room temperature in a 3:1 mixture of $95 \%$ ethanol : glacial acetic acid for $10 \mathrm{~h}$ and transferred to $70 \%$ ethanol for longer storage. For mitotic analyses, root tips were squashed in a drop of $1 \%$ aceto-orcein.

The percent seed germination was determined by planting 300 seeds/entry (in three replications of 100 seeds each) in seedling trays in the greenhouse on 18 Feb. 1988. Two weeks later, the number of seedlings produced per replication was counted, and 20 seedlings from each entry were transferred to pots containing sandy loam soil mix enriched with essential elements. Plants flowered in September and mature seeds were obtained in late Oct. 1988. Immature flower buds were fixed and meiotic analyses were performed on pollen mother cells (PMCS) by the procedures of Hashemi et al. (1986).

The percent seed germination averaged $98 \%$ $\pm 2 \%, 80.6 \% \pm 3.5 \%$, and $62 \% \pm 5 \%$ for seeds from Mexico, southern California, and Guatemala, respectively. The mature plants had ovate leaves (5 to $7 \mathrm{~cm}$ long), dense racemose inflorescences, and pale-blue flowers with the corolla tube as long as the calyx. Comparisons of the mature plants with herbarium specimens of the Rancho Santa Ana Botanical Garden, Claremont, Calif., indicated that they belonged to Salvia hispanica, an annual species that is distributed in Mexico and Peru and is naturalized in the West Indies (Bailey, 1976). Voucher specimens were deposited at the Univ. of California, Riverside, Herbarium.

Somatic chromosome counts of 50 root tips disclosed "a chromosome number of $2 n$ 


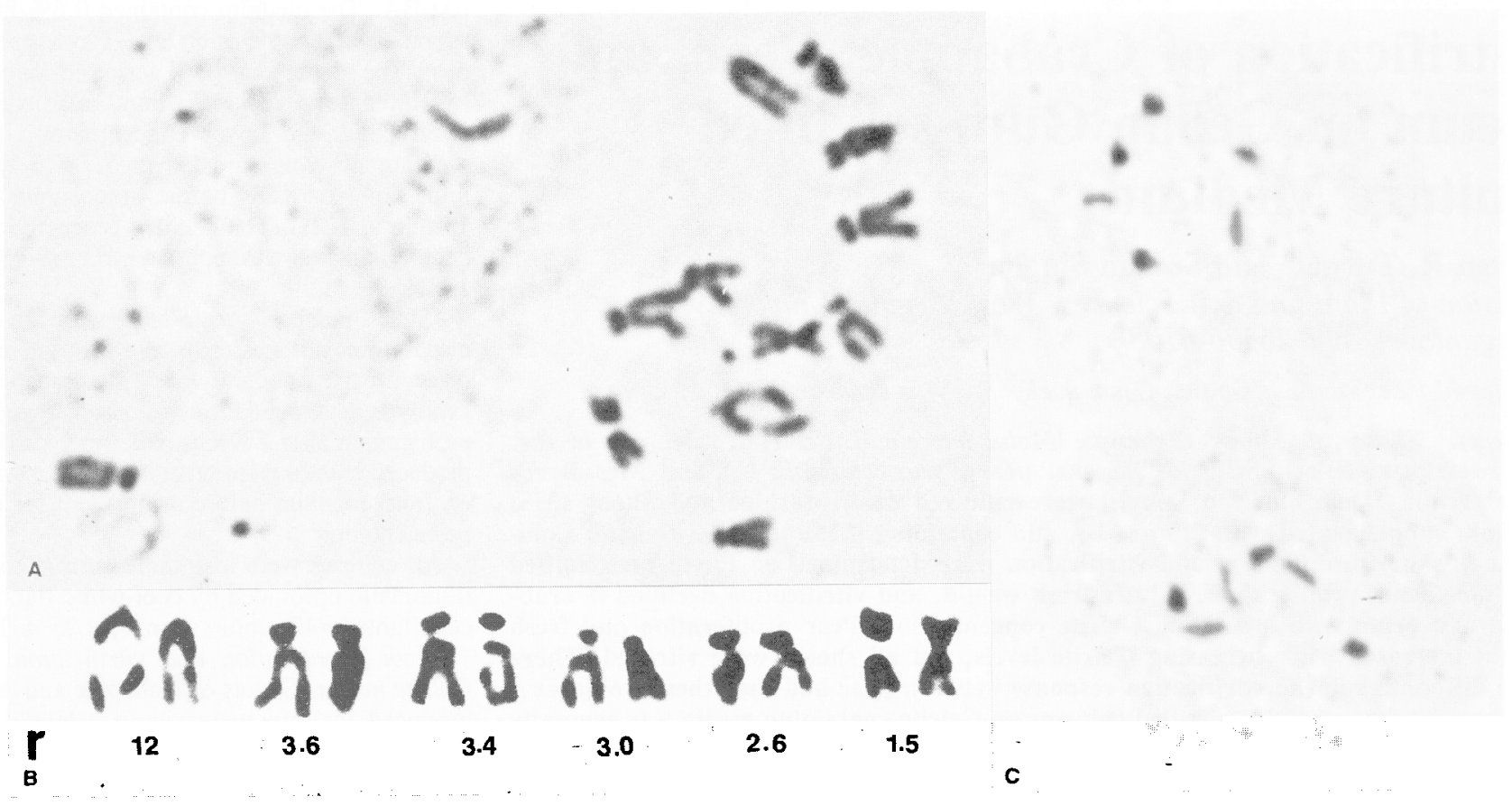

Fig. 1. Somatic chromosome number, karyotype, and meiotic chromosome pairing in Salvia hispanica. (A) Somatic chromosome number of $2 n=12$. (B) Chia karyotype. (C) Two cells at meiotic metaphase 1, each showing six bivalents.

$=12$ (Fig. 1A), the lowest known in the genus (Haque and Ghoshal, 1980). Chromosomes were small, ranging from 2 to 3.5 $\mu \mathrm{m}$ in length at mitotic metaphase. The somatic chromosome complement consisted of six pairs: one metacentric pair (long arm : short arm ratio, $r=1.5$ ), four submetacentric pairs ( $\mathrm{r}$ ranging from 2.6 to 3.6), and one telocentric pair $(\mathrm{r}=12)$. A karyotype for $S$. hispanica, based on chromosome length, position of centromere, and $r$ value, is p-resented in Fig. 1B. Consistent with mitotic chromosome counts, examination of 68 PMCs revealed six bivalents at diakinesis and metaphase I (Fig. 1C). Ring and rod bivalents averaged $1.53 \pm 1.05$ and $4.47 \pm 1.05$, respectively

The present investigation showed that the edible seed sold in the local markets of Mexico and Guatemala as chia represents $S$. hispanica with $2 \mathrm{n} .=12$. Salvia tiliifolia, $S$. columbariae, and S. carduacea, which are also referred to as chia, have been reported to have $2 n=22,26$, and 32 , respectively(Epling et al., 1962; Haque and Ghoshal, 1980; Stewart, 1939). To our knowledge, chromosome numbers have not yet been reported for the other two Salvia species (S. polystachya and S. lanceofolia) that are also known as chia.

\section{Literature Cited}

Bailey, L.H. 1976. Hortus third. Macmillan, New York.

Epling, C. 1938. The California salvias. A review of Salvia, section Audibertia. Ann. Missouri Bet. Gard. 25:95-188.

Epling, C., H. Lewis, and P.H. Raven. 1962. Chromosomes of Salvia, section Audibertia. Aliso 5:217-221.

Gill, L.S. 1971. Chromosome studies in Salvia (Labiatae), West Himalayan species. Experien- tia 27:596-598

Haque, Md.S. 1981. Chromosome number in the genus Salvia. Proc. Indian Acad. Plant Sci. 47:419-426.

Haque, Md.S. and K.K. Ghoshal. 1980. Karyotypes and chromosome morphology in the genus Salvia Linn. Cytologia 45:627-640.

Hashemi, A., J.E. West, and J.G. Waines. 1986. Chromosome pairing and pollen fertility in interspecific hybrids of species of Parthenium (Asteraceae). Amer. J. Bet. 73:980-988.

ortiz de Montellano, B.R. 1978. Cannibalism: An ecological necessity? Science 200:611-617.

Sanders, W.T. 1971. Settlement patterns in Central Mexico, p. 343. In: R. Wauchope (ed.). Handbook of Middle American Indians. vol. 10. Univ. of Texas Press, Austin.

Stewart, W.S. 1939. Chromosome number of California salvias. Amer. J. Bet. 26:730-732.

Vij, S.P. and S.K. Kashyap. 1976. Cytological studies in some North Indian Labiatae. Cytologia 41:713-717. 